Journal of Islamic Economics and Finance Studies

Volume 2, No. 2 (December, 2021), pp. 110-121

ISSN 2723 - 6730 (Print)

DOI. http://dx.doi.org/10.47700/jiefes.v2i2.3345

ISSN 2723 - 6749 (Online)

\title{
Small and Medium Enterprises Halal Literacy Measurement During Covid-19 Pandemic
}

\author{
Helma Malini \\ University of Tanjungpura \\ helma.malini@ekonomi.untan.ac.id
}

\begin{tabular}{l|l|l} 
Received: $1^{\text {st }}$ September 2021 & Revised: $8^{\text {th }}$ November 2021 & Published: $21^{\text {st }}$ December 2021
\end{tabular}

\begin{abstract}
The purpose of this study is to determine the level of halal literacy among Small and Medium Enterprises (SMEs) in Indonesia. The aspects studied are knowledge about halal behavior, halal attitude and halal knowledge. This research is a descriptive study based on a survey of research subjects using a purposive sampling technique. The population in this study were SMEs in Indonesia with a focus on the cities of Jakarta, Bandung, Surabaya and Pontianak with a total sample of 150 people. The sample was composed of owners of SMEs in Indonesia between the ages of 19 and 45 . The age group used as a sampling criterion is determined by the differences that may exist between age groups or generations. The results of the study indicate that the overall level of education in Indonesia, SMEs halal literacy is defined as sufficient literacy. It is hoped that the proposed measures of halal literacy in SMEs will assist policymakers in better understanding the level of literacy among SMEs to create a better halal ecosystem to improve economic resilience's toward crisis.
\end{abstract}

Keywords: Awareness; Economic Resilience; Halal Literacy; Small and Medium Enterprises

\begin{abstract}
Abstrak
Tujuan dari penelitian ini adalah untuk mengetahui tingkat literasi halal pada Usaha Kecil Menengah (UKM) di Indonesia. Aspek yang dipelajari adalah pengetahuan tentang perilaku halal, sikap halal dan pengetahuan halal. Penelitian ini merupakan penelitian deskriptif berdasarkan survei terhadap subjek penelitian dengan menggunakan teknik purposive sampling. Populasi dalam penelitian ini adalah UKM di Indonesia dengan fokus kota Jakarta, Bandung, Surabaya dan Pontianak dengan jumlah sampel 150 orang. Sampel terdiri dari pemilik UKM di Indonesia antara usia 19 dan 45 tahun. Kelompok usia yang digunakan sebagai kriteria pengambilan sampel ditentukan oleh perbedaan yang mungkin ada antara kelompok usia atau generasi. Hasil penelitian menunjukkan bahwa secara keseluruhan tingkat pendidikan di Indonesia, literasi halal UKM didefinisikan sebagai literasi yang cukup. Diharapkan langkah-langkah literasi halal yang diusulkan di UKM akan membantu pembuat kebijakan dalam lebih memahami tingkat literasi di kalangan UKM untuk menciptakan ekosistem halal yang lebih baik untuk meningkatkan ketahanan ekonomi terhadap krisis.
\end{abstract}

Kata kunci: Kesadaran; Ketahanan Ekonomi; Literasi Halal; UKM 


\section{INTRODUCTION}

Literacy is a complex set of abilities to comprehend and apply a culture's dominant symbol system to one's own and one's community's development, as well as to that of others. The concept of literacy develops as a result of the ability to comprehend information from various social and cultural contexts in response to changing needs and demands. The primary definition of literacy continues to be a lifelong intellectual process of obtaining meaning from critical written or printed text that is interpreted by the individual. The key to all literacy is reading development, a skill development process that begins with the ability to understand spoken words and decode written words and culminates in the ability to comprehend text, context, and concepts at a deep level of understanding (Sobari et al., 2019; Haque \& Hindrati, 2020; Hosen \& Lathifah, 2020).

A person's ability to read and write plays an important role in his or her development as a person. Being able to read and write means being able to keep up with the latest developments, communicate effectively, and comprehend the most recent relevant issues in order to respond to development challenges and the rapidly changing global environment, among other things. As a result, literacy is a critical foundation for providing Human Resources (HR) who are dependable, professional, and internationally competitive in any field, including Islamic economics, regardless of their educational background. The context of today's literacy is expanding to the point where it can be used to assess the depth to which concepts and products have been introduced into society in recent years. With the world's largest Muslim population, Indonesia has a low level of literacy in sharia instruments, as evidenced by the Economic Literacy Index and National Sharia Social Finance, both of which are only 16.2 percent of the population (Adinugraha et al., 2019; Hakim, 2015; Nugroho et al., 2020). Low sharia literacy includes the concept of halal which is currently the most talked-about and has emerged as a relevant issue that has great potential, specifically in relation to the concept of Islam.

In Islam, halal refers to things that are legal or permissible, whereas haram refers to things that are forbidden. Hadiths are used to explain what is halal and what is haram. However, there is a lack of knowledge and understanding of halal among halal trade operators, particularly among Muslims. Halal and haram are frequently only considered in the context of the production of goods. Halal, on the other hand, refers to all aspects of life in Islam. Halal is a broad term that refers to everything that is permissible under Islamic law (Elasrag, 2016; Suyatman et al., 2018). When viewed from an Islamic perspective, the concept of halal is extremely important for a Muslim to understand. In Islam, the term halal refers to something that is permitted or allowed (Nugroho et al., 2020). As a result, Muslims will look for products that are in accordance with accepted religious teachings in order to consume them. Allah swt. says in chapter Al-Baqarah verse 168. 


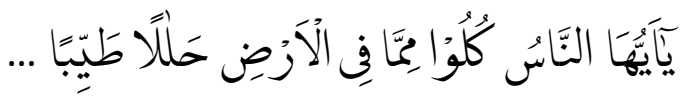

O mankind, eat what is lawful and good (thayyib) from what is on earth...

The interesting thing about the verse above is that the call is addressed to all 'human beings', not just Muslims. This proves that halal and thayyib are universal. We already know that halal is anything that is religiously allowed. The term thayyib literally means good. Broadly speaking, thayyib means things that are useful and not harmful to the body and mind. For example, halal food that contains balanced nutrition and does not damage can be said to be thayyib. However, foods that are halal but have bad side effects, such as containing high sugar levels for people who have a history of diabetes cannot be categorized as thayyib. Along with the times, thayyib can be interpreted with standards of feasibility, cleanliness and functional effects for humans (Zaroni, 2012; Wilson, 2014; Misbach, 2017; Hosen \& Lathifah, 2020; Nugroho et al., 2020).

Literacy is just as critical in Indonesia's development of a halal economic growth. Literacy is divided into two categories by the target, namely literacy for entrepreneurs and literacy for society. Indonesia, where Islam is the majority religion, still has a low level of halal awareness. This is reflected in the perception that when a seller or waitress wears an Islamic identity, such as a kopiyah or a hijab, it is impossible for them to sell non-halal products. Even though halal refers to not only substances that are not readily visible to the naked eye, such as food additives (flavoring, coloring, thickener, and others) for food products and processed foods, but also to the entire manufacturing process from upstream to downstream (Pintoet al., 2014; Aziz \& Ahmad, 2018; Sukardani et al., 2018).

COVID-19's existence is a source of contention for a variety of sectors. Following the pandemic, people adopted a policy of physical distancing. This undoubtedly has an effect on economic sectors, including those associated with the halal lifestyle. With the Covid-19 pandemic, sharia principles will become more relevant in the future. Naturally, this would be an excellent opportunity to further the development of Islamic economics, including a halal lifestyle. This condition persists, and it necessitates systematic management and synergy between institutions at all levels, from national to regional, and from micro to macro (Josephet al., 2020; Pitaloka et al., 2020). These actions can be classified as attempts to mitigate the risk of a pandemic of Covid-19. Covid-19 recovery has progressed since state leaders declared it a pandemic outbreak in response to a request from the World Health Organization (WHO) in late February 2020, but it has not been able to completely resolve the COVID-19 outbreak. Along with traditional taxation, shariabased taxation such as zakat and waqf, as well as the halal industry, can be explored to assist in alleviating the pandemic's burden since Indonesia's halal industry, which encompasses halal food and beverage, halal fashion, halal tourism, and halal 
management, is still dominated by small and medium-sized businesses (Amri, 2020; Pakpahan, 2020).

In Indonesia, the demand for halal products has grown significantly and keep on growing despite the COVID-19 pandemic, particularly in the food and beverage industry as well as cosmetics, pharmaceuticals, and other industries. According to data from the Indonesia National Committee of Shariah Economic and Finance, the demand of halal product is expected to generate approximately US\$330,5 million by the year 2025 (Samori \& Salleh, 2015; Timur, 2018; Putri \& Sunesti, 2021). However, data also showed that almost 65 percent of the sectors are coming from small and medium enterprises. SMEs which has significant potential for expanding the country's Halal industries and serving as an early stage in the development of halal literacies (Elasrag 2016). This reality does not appear to be fully realized due to the lack of halal literacy, particularly in terms of advancing a viable halal industrial ecosystem through the of halal literacy. As part of the process of developing halal industries in Indonesia, a specific type of business must be established with a strong focus on the of the country's economy.

There are currently 34 provinces in Indonesia that are home to the growth of Small and Medium Enterprises in Indonesia. Currently, the provinces with the highest concentrations of SME's are located in Central Java, East Java, and West Java (BPS, 2020). A large number of SMEs on the island of Java have been affected by the economic downturn and the instigation of entrepreneurship activities in the region. Kalimantan Island is home to the fourth largest number of SMEs in Indonesia, with West Kalimantan occupying the second-highest position among the provinces in the state of West Kalimantan (BPS, 2020). Table 1. shows the development of SMEs in Indonesia from 2018 up to 2019.

Table 1. Small and Medium Enterprises Development in Indonesia (2018-2019)

\begin{tabular}{lcccc}
\hline \multirow{2}{*}{ Indicator } & \multicolumn{2}{c}{$\mathbf{2 0 1 8}$} & \multicolumn{2}{c}{2019} \\
\cline { 2 - 5 } & Number & Market Share & Number & Market Share \\
\hline Business Unit & & & & \\
Small and Medium & 64.194 .057 & 99,99 & 65.465 .497 & 99,99 \\
Enterprises & & & & \\
Micro Business & 63.350 .222 & 98,68 & 64.601 .352 & 98,67 \\
Small Business & 783.132 & 1,22 & 798.679 & 1,22 \\
Medium Business & 60.702 & 0,09 & 65.465 & 0,10 \\
\hline
\end{tabular}

Source: Ministry of Cooperatives and SMEs of the Republic of Indonesia, 2020

The government's ability to create a healthy SMEs industry will be limited by a lack of halal knowledge. Furthermore, during an economic downturn, SMEs with a higher level of Halal knowledge have a lower negative impact (Misbach, 2017). Among them are: 1) SMEs play a significant role in the Indonesian economy; 2) SMEs are also the most labor-intensive sector. This practice must be supported and aligned with the government's ongoing efforts to reduce unemployment; and 3) the SMEs sector is thought to be the most resilient in times of economic crisis. 
Therefore, the existence of the current problems and gaps between the growth of economy, economy as well as the lack of literacy deliver the need to strengthen the understanding of education and awareness of producers and consumers of the halal concept are the basis for this study. Furthermore, halal literacy is a bridge for SMEs to survive and become strong in the midst of a crisis because they practice halal principles in which there is the principle of sustainability so that they can survive crises and challenges. Halal literacy can encourage SMEs to increase company size and make it possible for companies to form more efficient, healthy, fair and transparent organizations.

A few researchers focused on halal literacy especially in SMEs. Therefore, this research intends to analyze measurement of the level of halal literacy among SMEs. The objective of this research is to determine the level of halal SMEs literacy in Indonesia so that relevant parties can take approaches and policies to increase halal literacy so as to create SMEs and healthy economic growth. The outcome of this measurement will assist the government and related parties in the SME sector in increasing halal literacy in order to stimulate economic activity from an Islamic economic perspective. Given Indonesia's majority Moslem population, this will serve as a solid foundation for the establishment of strong SME's in the future.

\section{LITERATURE REVIEW}

Prior research has frequently used the concept of literacy to describe a variety of consumer behaviors. However, because literacy has not been conceptualized in the context of halal eating behavior, an initial study of the definitions and applications of literacy principles in other behavioral contexts would be necessary to provide the groundwork for the concept of halal literacy. Financial literacy is one sort of literacy that has received extensive study interest. Huston (2010) used financial literacy to explain various investor behaviors as financial services customers, as did some researchers (Mandell \& Klein, 2009; Lusardi \& Mitchell, 2011; Fernandes et al., 2014). A study by Danes et al. (1999) found that kids who have more financial knowledge and information, whether from their parents or from other sources, save more money. Kramer (2016) find that investors with little financial literacy are more prone to optimism bias, both internal and external.

Along with financial literacy, the concept of literacy has been utilized to describe customer perceptions and behaviors in several contexts. Media literacy is another context of literacy that has recently gained scientific interest. Islamic financial literacy has been identified as a critical tool for promoting inclusion. However, despite an attempt in the past, structures for Islamic financial literacy have not been sufficiently studied until now. As a result, it aspires to create structures for Islamic financial literacy and education. The factors that influence it It's not just about halal ingredients and production in the halal industry. Aside from halal production, the right halal business operators should also focus on halal marketing. Focus on 
implementing halal financing, also known as Islamic financing. However, the evaluation of the level of halal and Islamic awareness, knowledge, and skills it is necessary to plan for financing among business owners. (Mandell \& Klein, 2007; Huston, 2010; Kramer, 2016; Haque \& Hindrati, 2020). Unlike more generic cognitive categories like awareness and participation, literacy was used in each of these studies.

This is a more particular concept of consumer cognition than the other. Literacy is a condition of awareness of particular concepts or a desire to learn more about certain topics. Literacy is the ability to change one's own conduct as a result of better understanding a topic or issue. To Nugroho et al. (2020), literacy is both potential and enactment (or actualization). Potential literacy includes three components: knowledge of a situation, personal involvement in that context, and social contact with others. Enactment requires a set of skills that assist shape the situation: identifying needs, voicing concerns, participating in the process, and assessing the outcomes. These criteria were originally created for use in other contexts of literacy; however, they may be appropriate for application in Halal food consumption.

In general, there are two ways to evaluate literacy. Using attitude items to assess self-evaluation results in perceived literacy, while administering test-based items results in actual literacy. Self-evaluation of competence or self-efficacy may have a greater influence on behavior than actual competency, according to Pinto et al. (2014), especially when the individual's self-evaluation is lower than actual competence. Contrarily, self-evaluation measurement can be highly subjective due to a variety of unconscious or conscious biases.

Haque \& Hindrati (2020) discovered that self-rated and actual financial literacy are frequently mismatched, with investors overrating themselves most of the time. The findings of backed up this conclusion. The inability of low-literate people to objectively assess their own competence level may be to blame for these discrepancies. The overconfidence bias and the metacognitive deficiency bias are synonyms (Pinto et al., 2014). The concept of halal literacy was thus tested for bias using both self-reported and test-based measurements. The author proposed the following theoretical framework in Figure 1.

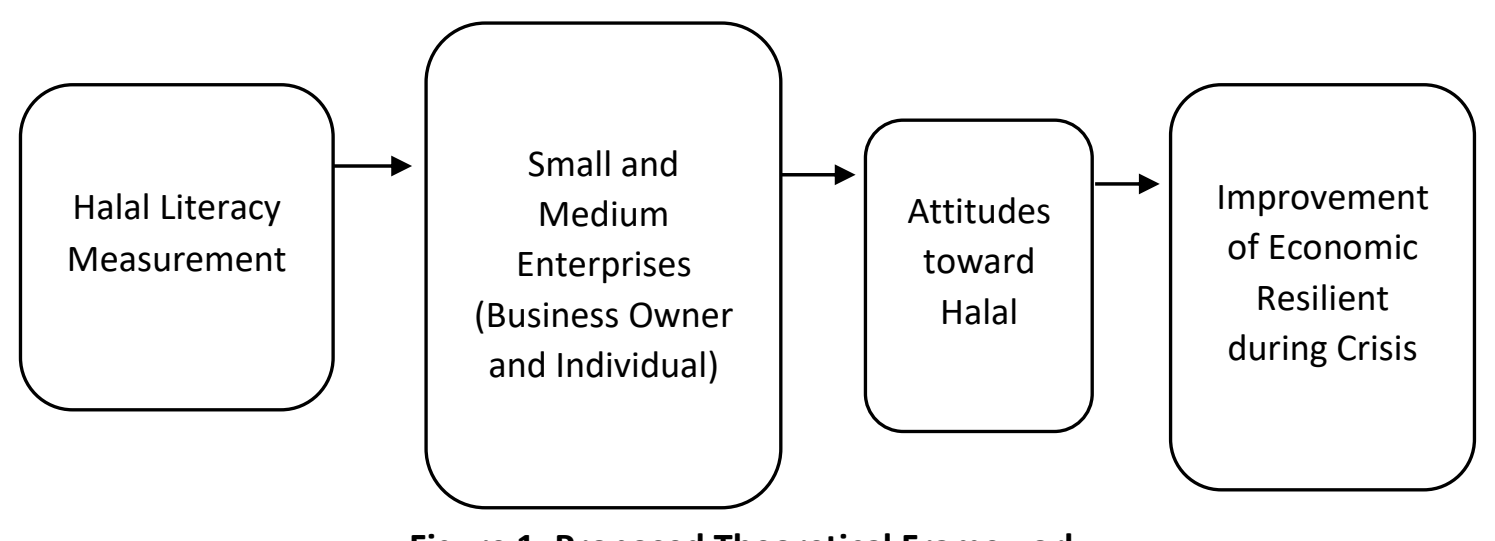

Figure 1. Proposed Theoretical Framework 


\section{RESEARCH METHOD}

This research is a descriptive study based on a survey of research subjects, and the findings can provide an accurate picture of halal literacy in SMEs. This study surveyed 150 respondents using a purposive sampling technique in several cities in Indonesia, as it is listed in Table 2. The sample was composed of owners of SMEs in Indonesia between the ages of 19 and 45 . The age group used as a sampling criterion is determined by the differences that may exist between age groups or generations.

A questionnaire was used to gather information. The distributed questionnaire contained general information about halal attitudes, halal behavior, and halal knowledge. All prohibitions in Islamic laws (sharia) are listed in detail in the operational definition used in this study, which is based on the definition in the Encyclopedia of Prohibitions chapter on Food by Shaykh Salim bin led Al-Hilali (2005b). Because the emphasis is not only on understanding the basic concept of halal, but also on its proper application, only 12 people passed the final data collection after the pre-test. To obtain the results of the halal literacy level in the form of questions encompassing halal attitude, halal behavior, and halal knowledge. The criteria for measuring the level of halal literacy are high if the correct score exceeds 80 percent, medium if the correct score is between 60 percent and 80 percent, and low if the correct score is less than 60 percent. The data analysis method used was descriptive analysis, which is a technique for describing the phenomena or characteristics of data. Frequency, percentage, average, and standard deviation of research data are among the observed characteristics. Respondents' answers to 12 questions for SMEs and 12 individual questions for actors, adapted from Shaykh Salim bin led Al-Hilali, were used to determine the level of halal literacy (2005b). The correct answer is calculated, then divided by all of the questions and multiplied by $100 \%$. This study describes halal decisions based on the personal halal behavior of SME actors, in addition to questions about halal literacy.

Table 2. Distribution of Research Samples for SMEs During Covid-19 Time Period March 2020-May 2021

\begin{tabular}{llc}
\hline \multicolumn{1}{c}{ Small and Medium Enterprises } & City & Number of Sample \\
\hline Jakarta & Jakarta & 40 \\
Bandung & Bandung & 40 \\
Surabaya & Surabaya & 40 \\
Pontianak & Pontianak & 30 \\
\hline Total & & $\mathbf{1 5 0}$ \\
\hline
\end{tabular}

Source: Author, 2021 


\section{RESULT AND DISCUSSION}

Table 3 shows that the percentage of people who correctly answered the question HLL01 was $10.67 \%$. The average respondent who correctly answered questions about HLL02 was 64.67 percent, with a 12.67 percent error rate and a 22.66 percent abstention rate. For question HLL03, which asks if the respondent is aware that most rum used in cakes contains pork, 40 percent of respondents answered correctly, 22.00 percent incorrectly, and 38.00 percent abstained. This indicates that half of the respondents are still unsure about whether the Rum they use to make the cake is pork-free or not. This uncertainty stems from SMEs owners' lack of knowledge about the content of the ingredients they use, as well as their belief that all cake ingredients can be certified as halal. Meanwhile, 40.57 respondents correctly answered questions in the HLLO4 section, while 35.33 incorrectly answered. Question HLLO4 focuses on knowledge of edible marine animals, specifically whether fish fed dirty food can be sold or fit for consumption.

Table 3. Descriptive Statistics on the Distribution of Respondent Correct, Incorrect, and Abstain Answers

\begin{tabular}{ccccc}
\hline ITEMS & True & False & Abstain & Difficulty \\
\hline HLL01 & $10.67 \%$ & $64.00 \%$ & $25.33 \%$ & Low \\
HLL02 & $64.67 \%$ & $12.67 \%$ & $22.66 \%$ & Low \\
HLL03 & $40.00 \%$ & $22.00 \%$ & $38.00 \%$ & Moderate \\
HLL04 & $40.67 \%$ & $35.33 \%$ & $24.00 \%$ & High \\
HLL05 & $25.33 \%$ & $23.33 \%$ & $51.33 \%$ & High \\
HLL06 & $36.00 \%$ & $15.33 \%$ & $48.67 \%$ & Moderate \\
HLL07 & $9.33 \%$ & $46.67 \%$ & $44.00 \%$ & Low \\
HLL08 & $18.67 \%$ & $19.33 \%$ & $62.00 \%$ & Low \\
HLL09 & $68.00 \%$ & $6.67 \%$ & $25.33 \%$ & High \\
HLL10 & $28.00 \%$ & $30.67 \%$ & $41.33 \%$ & Moderate \\
HLL11 & $40.00 \%$ & $22.00 \%$ & $38.00 \%$ & Moderate \\
HLL12 & $85.33 \%$ & $8.00 \%$ & $6.67 \%$ & Moderate \\
\hline
\end{tabular}

Source: Author, 2021

With the assumption that SME's owners are mostly food business owners, the portion of the correct answer to this question is large enough that knowledge about dirty things that cannot be used as food is good enough among SME's owners. The abstention rate was quite high for questions HLL05 and HLL06, where the focus of the question was on whether pork was the only food that Muslims could not eat and whether horses (for example) could be eaten and used in cooking. Questions HLL05 and HLLO6 focus on in-depth knowledge of halal, requiring at least a basic understanding of the concept of halal from reading a book or attending a lecture or sermon on the subject.

Meanwhile, questions ranging from HLL07 to HLL12 are extremely extreme, particularly in the low literacy and high literacy sections. HLL07 (low literacy) with a 
focus on the question "Cigarettes are haram in nature because they harm the human body." This question necessitates a thorough understanding of the concept of halal, because while most people understand that cigarettes are harmful to their health, determining whether the content of cigarettes is harmful enough to make them haram for consumption necessitates further investigation. Meanwhile, nearly 85.33 percent of respondents correctly answered the HLL12 question, indicating a high literacy rate. It is not permissible to eat in a restaurant that also serves pork and alcohol, according to HLL12. The percentage of respondents who correctly answered this question demonstrates a good understanding that restaurants serving pork and alcohol should not be visited if there is a chance that the cooking ingredients or the cooking ingredients have been tainted with pork or alcohol.

The mapping that we can do to SMEs operators in Indonesia based on the above results is the occurrence of a medium level of moderation for Halal literacy of SMEs operators in Indonesia. Several questions can be answered correctly, and the abstention rate is low, as can be seen. More detailed questions, on the other hand, necessitate a high level of understanding, necessitating a higher level of literacy in order for SMEs operators in Indonesia to operate in accordance with Halal and sharia principles. The overall data related to the answers of respondents can be seen from Figure 2.

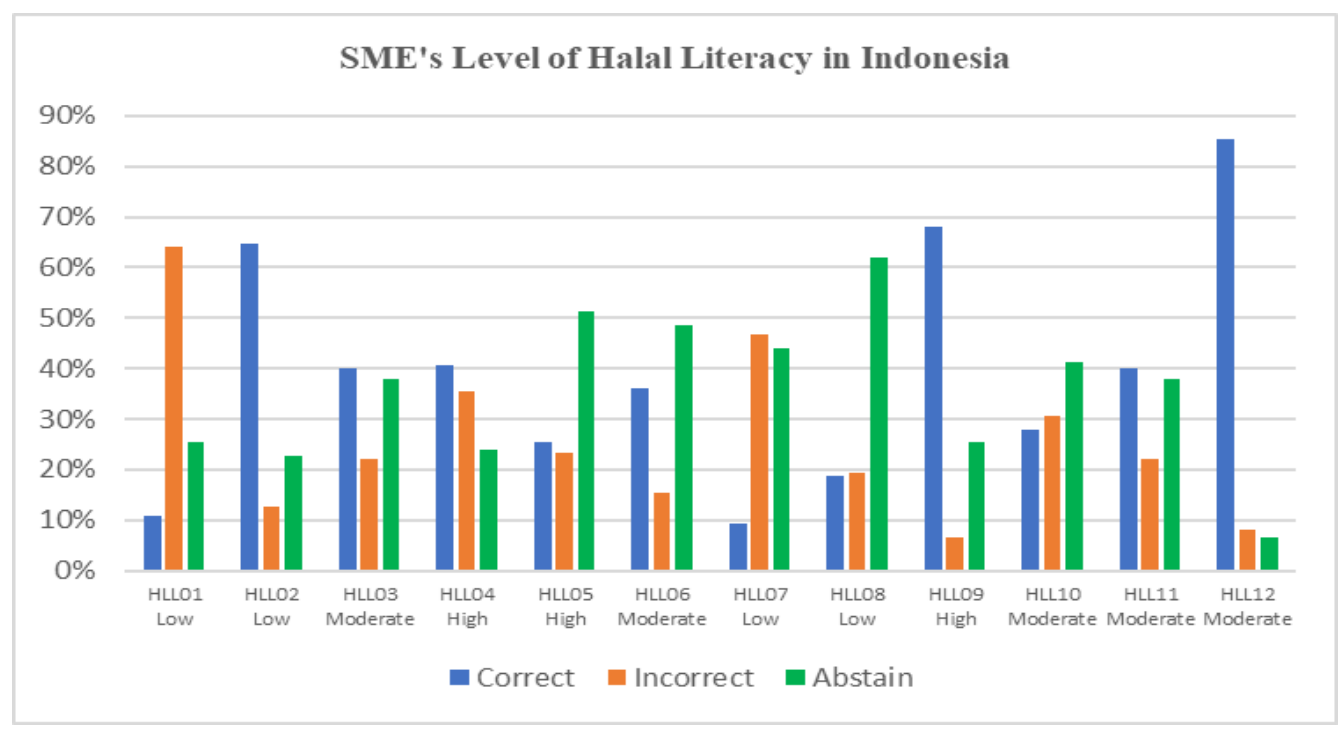

Figure 2. SME's Level of Halal Literacy in Indonesia

A total of 12 true and false questions were used to assess halal literacy. The proportion of correct and incorrect answers for each item was calculated in order to determine the difficulty of the item in question. Items with a low level of difficulty will have a high proportion of correct answers and a low proportion of incorrect answers. Items with a high degree of difficulty will have proportions, and vice versa. The low proportion of correct answers and the high proportion of incorrect answers are the reasons for this. A common method of calculating the incorrect proportion is to simply subtract the correct answer from 100 percent of the correct answer. 
However, because the option to abstain is provided in this case in order to eliminate guessing errors, incorrect proportions answers must be counted separately from correct proportions answers.

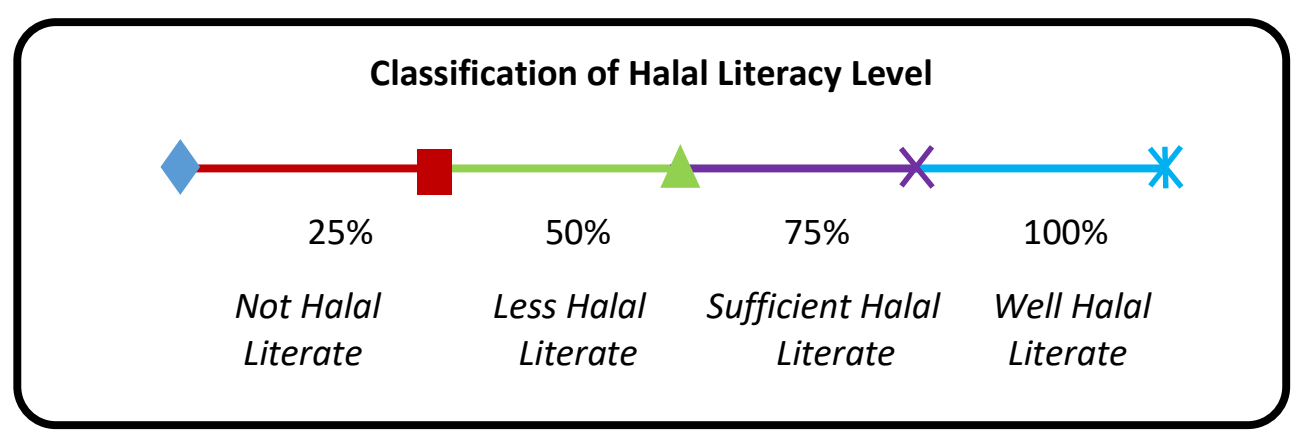

Figure 3. The classification of Halal Literacy Level

Figure 3 shows the classification of halal literacy level. Based on this classification, the components of halal knowledge are depicted in the research results presented in this section. The halal behavior component receives an average score of 55 percent, while the halal attitude component receives a score of 21 percent on the scale. In the halal component, specific knowledge is required. More research and application of halal behavior and attitude are required, as is an improvement in halal knowledge to facilitate the decision-making process in the implementation of SMEs business management and in making the appropriate halal decisions in order to improve the overall performance of the SME in Indonesia, SMEs have a high level of halal literacy shows a result of 54 percent, indicating that the overall level of education is In Indonesia, SME halal literacy is defined as sufficient literacy, implying that SMEs are both actors and individuals in their respective industries. The knowledge and belief that you have about halal should be strong, as should your halal behavior and attitude toward halal.

\section{CONCLUSION}

The level of understanding and literacy of small and medium business owners in Indonesia is measured in two ways: as a small and medium business owner and as an individual. It's important to keep in mind that the halal literacy instrument used in this study only included topics about food, snacks, and edible animals. The components of halal knowledge are depicted in the research results presented in this section, according to the findings of this study. On the scale, the halal behavior component receives a 55 percent average, while the halal attitude component receives a 21 percent average. Specific knowledge is required for the halal component. More research and application of halal behavior and attitude, as well as an improvement in halal knowledge, are needed to aid in the decision-making process in the implementation of SMEs business management and in making the appropriate Halal decisions in order to improve the overall performance of the SMEs in Indonesia, SMEs have a high level of halal literacy. SMEs halal literacy is defined as 
adequate literacy in Indonesia, implying that SMEs are both actors and individuals in their industries.

SMEs in Indonesia should be educated on halal literacy as soon as possible. Furthermore, because the halal concept is a very broad concept, not only does it not contain pork or not, related parties must use the halal literacy method, which is easy to understand by SME's and is carried out on a continuous basis. It is hoped that the proposed measures of halal literacy in SMEs will assist policymakers in better understanding the level of literacy among SME's, particularly from the perspective of Halal business owners and producers. However, the scope of this research is limited to business operators in the SMEs sector. Many other potential halal literacy topics, such as halal literacy financial transactions, clothing, drugs, and cosmetics, have yet to be measured. Owners of small and medium businesses can have a wide range of reactions to these various topics. As a result, the validation of the findings of this study is limited to the findings of this study.

\section{REFERENCES}

Adinugraha, H. H., Oktafiyani, M. and Mubtadi, N. A. (no date) HALAL LIFESTYLE: Theory and Practice in Indonesia. Zahir Publishing.

Amri, A. (2020) 'Dampak Covid-19 Terhadap UMKM di Indonesia', Jurnal Brand.

Aziz, N. I. A. and Ahmad, F. A. (2018) 'The Halal Lifestyle of Muslim Working Women', International Journal of Academic Research in Business and Social Sciences, 8(5), pp. 1138-1147.

Danes, S. M., Huddleston-Casas, C. and Boyce, L. (1999) 'Financial planning curriculum for teens: Impact evaluation', Journal of Financial Counseling and Planning, 10(1), p. 26.

Elasrag, H. (2016) Halal industry: Key challenges and opportunities. Hussein Elasrag.

Fernandes, D., Lynch Jr, J. G. and Netemeyer, R. G. (2014) 'Financial literacy, financial education, and downstream financial behaviors', Management Science, 60(8), pp. 1861-1883.

Hakim, A. L. (2015) 'Dissecting the Contents of Law in Indonesia on Halal Product Assurance', Indon. L. Rev., 5, p. 88.

Haque, M. G. and Hindrati, D. (2020) 'Investigating Awareness \& Knowledge, Halal Logo and Religiosity Affecting Decision and Lifestyle to Consume Halal Culinary; Case Study of Three Indonesian Regions in Japanese Restaurant', Jurnal IImu Manajemen \& Ekonomika, 12(1), pp. 27-31.

Hosen, M. N. and Lathifah, F. (2020) 'Comparison of Halal Certification in Several Countries toward Halal Standard of Indonesia'.

Huston, S. J. (2010) 'Measuring financial literacy', Journal of consumer affairs, 44(2), pp. 296-316.

Joseph, O. P., Tulung, J. E. and Wangke, S. (2020) 'Impact of social media marketing towards business performance of MSMES in Manado during COVID-19 pandemic', Jurnal EMBA: Jurnal Riset Ekonomi, Manajemen, Bisnis dan Akuntansi, 8(4). 
Kramer, M. M. (2016) 'Financial literacy, confidence and financial advice seeking', Journal of Economic Behavior \& Organization, 131, pp. 198-217.

Lusardi, A. and Mitchell, O. S. (2011) 'Financial literacy around the world: an overview', Journal of pension economics \& finance, 10(4), pp. 497-508.

Mandell, L. and Klein, L. S. (2007) 'Motivation and financial literacy.', Financial services review, 16(2).

Mandell, L. and Klein, L. S. (2009) 'The impact of financial literacy education on subsequent financial behavior', Journal of Financial Counseling and Planning, 20(1).

Misbach, I. (2017) 'Perilaku Bisnis Syariah', Al-Idarah, 5, pp. 33-44.

Nugroho, I. S., Bhagya, T. G. and Rosinawati, D. (2020) 'Industri dan Supply Chain Halal dilihat dari Aspek Keilmuan Teknik Industri', Sainteks: Jurnal Sains dan Teknik, 2(2), pp. 58-71.

Pakpahan, A. K. (2020) 'COVID-19 dan Implikasi Bagi UMKM', Covid-19 Dan Implikasi Bagi Usaha Mikto, Kecil, Dan Menengan.

Pinto, M., Pulgarín, A. and Escalona, M. I. (2014) 'Viewing information literacy concepts: a comparison of two branches of knowledge', Scientometrics, 98(3), pp. 2311-2329.

Pitaloka, H. et al. (2020) 'The economic impact of the COVID-19 outbreak: Evidence from Indonesia', Jurnal Inovasi Ekonomi, 5(02).

Putri, A. K. and Sunesti, Y. (2021) 'Sharia Branding in Housing Context: A Study of Halal Lifestyle Representation', JSW (Jurnal Sosiologi Walisongo), 5(1), pp. 77-92.

Rusni, H., \& Nur I'ffah, M. N. (2016). Prioritization of Zakat Distribution in Selangor and the Federal Territory of Malaysia : Are They Following the Right Distribution Principles According to Shariah? Intellectual Discourse, 4878(Special Issue), 435-457.

Samori, Salleh, D. (2015) 'Current Trends In Halal Tourism: Cases on Selected Asian Countries', in, p. hlm. 132.

Sobari, N., Kurniati, A. and Usman, H. (2019) 'The influence of Islamic attributes and religious commitments toward halal wellness services customer satisfaction and loyalty', Journal of Islamic Marketing.

Sukardani, P. S., Setianingrum, V. M. and Wibisono, A. B. (2018) 'Halal lifestyle: current trends in Indonesian Market', in 1st International Conference on Social Sciences (ICSS 2018). Atlantis Press, pp. 334-339.

Suyatman, U., Ruminda and Yatmikasari, I. (2018) 'Pulau Lombok: Pengembangan Wisata Halal dalam Bingkai Kearifan Lokal', pp. 1-99.

Timur, U. P. N. V. J. (2018) 'Halal Lifestyle: Current Trends In Indonesian Market'.

Wilson, J. A. J. (2014) 'The halal phenomenon: an extension or a new paradigm?', Social Business, 4(3), pp. 255-271.

Zaroni, A. N. (2012) 'Landasan Filosofis Perilaku Konsumen Dalam Perspektif Ekonomi Islam Dan Konvensional', Mazahib, 10(1). 